\title{
University students' perception of online learning: A case study of Virtual Class learning management system in the University of Lampung
}

\author{
Fajar Riyantika ${ }^{1^{*}}$ \\ Khairun Nisa ${ }^{2}$ \\ Budi Kadaryanto ${ }^{3}$ \\ 1,2,3 English Education Study Program, University of Lampung, Bandar Lampung, Indonesia
}

\begin{abstract}
The use of online media to facilitate distant learning during the pandemic has become one of the solutions that can be implemented to support the government's policy of reducing crowds in public spaces. In this case, students at the University of Lampung's Faculty of Teacher Training and Education benefit from an online management system called Virtual Class Unila. This platform is intended for students to use to access resources, download learning modules, and participate in classroom discussions. The Virtual Class was created to assist students with distance learning. However, since the initial implementation of Virtual Class at the start of the pandemic in early 2020 , both positive and negative perceptions about its use have emerged. As a result, we were encouraged to ascertain diverse perceptions regarding the use of this sophisticated learning management system among students at the Faculty of Teacher Training and Education, University of Lampung. This study employed a quantitative approach, collecting data via a scaled survey questionnaire. The target participants were 272 students from various departments who were asked to complete a survey regarding their perceptions of the implementation of Virtual Class. The findings of this study are expected to be beneficial for the future maintenance and development of Virtual Class, as well as for determining the optimal method of conducting online learning.
\end{abstract}

\section{KEYWORDS}

Virtual Class; online learning; perception

Received: 30 September 2021 Accepted: 3 October 2021 Published: 4 October 2021

\section{Introduction}

Since the past two years, varied online learning management systems have been widely used due to the policy of distant learning during pandemic situation. The conventional face to face classrooms has turned into video conference sessions, and asynchronous discussions in group messengers. More than that, the submission of assignments, projects, and tasks has been heavily digitalized. All of the processes in transforming the traditional teaching and learning way into such sophisticated online learning situation have forced the teachers, lecturers, and all educators to optimize the use of the Internet, especially the online learning management system to support their primary duty in implementing teaching and learning process. (Adzharuddin \& Ling, 2013) found that university students during the early development of Learning Management System (LMS) viewed LMS as something that was very essential in supporting the process of learning especially to provide more chances to conduct distant learning.

Regarding the current situation due to pandemic, implementing distant learning through several platforms, especially LMS, in the internet has become common practice around the world. Therefore, during this pandemic situation within the last two years, the University of Lampung has optimized the use of their online learning management system known as Virtual Class Unila. The learning management system (LMS) was created and firstly implemented in 2016. During its active implementation, especially during the pandemic situation since 2020, several upgrades and maintenances have been carried out to improve the efficacy of the system and features within the platform. The improvement of Virtual Class Unila has reached a new level which allows the students and lecturers to use Google Meet and HTML5 as integrated platforms within the LMS. Thus, such a significant upgrade 
triggers several pre-assumptions regarding students' perception of Virtual Class full implementation during the COVID-19 pandemic situation. (Kobayashi, 2017) emphasized in her study in the implementation of online media that students' preferences and perceptions in using such internet-based media were driven by their familiarity towards the media. Thus, changes and development in LMS, specifically Virtual Class, might affect learners' familiarity, which will also influence their perspective about the LMS.

Several studies regarding the perceptions towards LMS have been conducted. (Adzharuddin \& Ling, 2013) mentioned the significance of LMS and how students reacted positively towards its implementation. (Gunduz \& Ozcan, 2017) analyzed the benefits and some weaknesses of LMS in general. However, specific study on students' perceptions towards the implementation of Virtual Class Unila in the Faculty of Teacher's Training and Education is still very limited. Therefore, this research is essential since it can be used as a guideline to identify weaknesses and hindrances within the system for further development of Virtual Class Unila in the future. Furthermore, the survey used in this research also identifies open-ended responses from the students regarding their thought about possible improvements for the Virtual Class based on their experience in using the platform. Therefore, it is aimed that the result of this result can transform Virtual Class into better LMS for the students of Unila to achieve better outcomes.

This research is intended to reach the following objectives:

1. To find out different perceptions on the implementation of Virtual Class Unila among students of FKIP Unila;

2. To analyze weaknesses, hindrances and benefits of using Virtual Class Unila based on students' perceptions and responses.

The expected results of this study are various perceptions regarding the use of Virtual Class Unila among students of Faculty of Teacher Training and Education, Lampung University during online learning situation. Moreover, the urgency of this research is to find out the advantages and disadvantages of Virtual Class Unila based on students' experience for at least the last year.

\section{Literature review}

\section{Online Learning}

(Aydin, 2007) analyzed students' behavior on various online digital media in EFL learning situations. It was found that most students reacted positively in response to using online digital media despite they also clearly understood that such internet-based platforms brought positive and negative impacts such as distraction, chance to become addicted, and unsafe contents. However, the positive reactions and the students' awareness regarding countless features in the Internet indicated the beneficial values that online digital media has, which allows students to experience better and more resourceful EFL learning.

In the current condition, where all teaching and learning processes occur online, internet-based digital media is one of the best options to optimize the teaching and learning processes. However, there are several issues in the implementation of online digital media in EFL learning situations. (Atmojo \& Nugroho, 2020) conducted research that involved English teachers and found out that there were several technical and non-technical problems. According to them, such problems were caused by lack of preparations, which led to ineffective application of online digital media in teaching and learning situations. Such hindrance was caused by an uneven distribution of facilities among schools in different regions, and also a lack of guidance regarding the use of online digital media.

(Zarei et al., 2018) conducted an experimental study and found that the use of online digital media contributed positively in students' learning achievement, specifically in language comprehension and vocabulary production. Thus, using online digital media has positive impact on the process of English as a foreign language.

(Ahmada \& YIN, 2019) found that modification and adaptation processes were essential in optimizing the online-based platform to be used in teaching and learning contexts. Moreover, integrating such modern media with conventional learning sources is important to promote a better learning experience for the students without losing the primary objective of the learning itself.

(RAO, 2019) discovered beneficial values within social media when such platforms were applied in EFL learning situation. It was found that the non-education based platform such as Instagram and Twitter significantly improved students' interactions in using English as the target language.

(Shafwati et al., 2021) found that the implementation of online YouTube videos in listening classes encouraged students at the undergraduate level to comprehend better listening materials and perform better in dealing with listening tests. Thus, it can be assumed that internet-based media can optimize the process of EFL learning. More than that, social media and YouTube content are often involved in various learning management systems including Virtual Class Lampung University. 


\section{Learning Management System (LMS)}

Virtual Class Lampung University is a Moodle-based learning management system which has been enriched with several supporting features. This research investigates perceptions on the use of a similar system, which has been enhanced and optimized. Therefore, several findings on LMS from previous studies are given.

(Gunduz \& Ozcan, 2017) explored students' and teachers' perceptions in the use of Moodle as a supporting learning management system in the secondary level of education. It was found that Moodle is useful for long-term use and can be used effectively with proper preparation. However, there will be several issues and ineffective use due to a lack of features during the time the research was conducted.

(Ippakayala \& El-Ocla, 2017) introduced a learning management system that integrated several features such as sources of materials, attendance list, and discussion forum, which could be applied in distant learning situations. They believed that modern education should implement such a learning management system to support distant learning to break the boundaries of time and space in learning.

(Turnbull et al., 2020) stated that LMS should consist of integrated media in one solid system that supports the process of teaching and learning. The finding clearly describes what LMS is, and proves that Virtual Class Unila can be categorized as LMS.

\section{Perceptions on Online Digital Media}

(Qiong, 2017) identified perception as a process of noticing and understanding sensory information to build a set of ideas related to the obtained information. Furthermore, Qiong mentioned three stages of perception: selection, organization, and interpretation. Selection involves the process of grasping and converting information into meaningful experience. Organization is a process of arranging the previously obtained information to find some meaningful patterns and interpretation is the process of classifying the patterns into different category. It was also stated that different individuals will not have the same perception regarding identical information as they might have different interpretation when grasping the information (Qiong, 2017).

Other study by (Koohang \& Durante, 2003) revealed that perception and attitude are major factors influencing motivation in distant learning. Thus, based on the concept of perception and the finding students' perceptions towards certain aspects of learning, such as media, will influence students way of learning especially in online learning situation.

(Kobayashi, 2017) found that the preference of using online digital media among students was based on their familiarity and self-efficacy in accessing the particular medium. It was identified that students' intensity in using a particular platform on the Internet would influence their preferences of online digital media.

(Muhammad et al., 2017) found that students preferred to have the teacher explaining materials using interactive media such as videos and other digital platforms. This finding was in line with (Aydin, 2007) who identified positive responses from students regarding using online digital media in EFL learning situations.

(Smart \& Cappel, 2006) compared the application of internet-based digital modules in two different classes: compulsory class and optional class. In mandatory class, the students used an internet-based digital module with strict regulations to use all features. Meanwhile, the students in the optional class got more freedom to choose their preferred features and media to use. The findings showed that students from optional classes experienced better learning based on their positive perspectives regarding the use of the digital module. Thus, it is proven from the findings of Smart and Cappel study that it is crucial to choose several features out of countless possible features within internet-based media to be used in EFL learning situations.

The previous studies above are in line with the current study on students' perceptions on the use of Virtual Class as a learning management system.

\section{Methods}

This study is a survey-based study whose objective is to identify undergraduate students' perception of the use of Virtual Class Lampung University during online learning situations. Students' perceptions were obtained using a set of close-ended questionnaire items. Exploring students' perceptions in this case is considered essential since it will be beneficial for the development of Virtual Class Unila in the near future.

\section{Participants}

The participants of this study are students from the Faculty of Teachers' Training and Education. Two hundred seventy two students responded to the online questionnaire form. The participants were within the age of 18-22 year-old and they came from seven departments. The questionnaire was distributed via Google Form on the first week of August 2021. 


\section{Instruments}

A set of the Likert-scale questionnaire is used to obtain the data for this study. The instrument consists of 14 items with the range of 1 to 4 for each item. One open-ended item is also used to obtain a more comprehensive response regarding students' personal perspectives about Virtual Class Unila.

The questionnaire was developed by the referring to several theories of perceptions, especially in the context of online learning using LMS. The items carried by the questionnaire are related to the concept of organization and interpretation process by (Qiong, 2017). The students' were given statements that are related to how they experienced Virtual Class implementation during the online learning situation.

Therefore, the questionnaire was designed to obtained responses regarding: perceptions towards different features in Virtual Class Unila, perceptions towards the implementation of Virtual Class in distant learning, and perceptions towards benefits and weaknesses of Virtual Class Lampung University.

\section{Data analysis}

In general, the process of collecting data was divided into some steps. The first one was a preparation that included the following activities: 1) designing the instrument, 2) distributing the instrument, 3) reliability checking and analysis, 4) revision, and 5) finally transferring the questionnaire to Google Form to be later distributed to students in the Faculty of Teacher Training and Education.

Given below is the table showing the reliability level of the questionnaire after being checked using Cronbach's Alpha.

Table 1. Consistency level of the questionnaire analyzed using Cronbach's Alpha

\begin{tabular}{ccc}
\hline & \multicolumn{2}{c}{ Reliability Statistics } \\
\hline Cronbach's Alpha & $\begin{array}{c}\text { Cronbach's Alpha Based } \\
\text { on Standardized Items }\end{array}$ & N of Items \\
\hline .696 & .706 & 13 \\
\hline
\end{tabular}

The reliability level of the questionnaire can be considered quite high as it reaches the value of 0.7 . Thus, the questionnaire is consistent enough to be applied in a survey-based study

The next phase is obtaining responses from the participants. The researchers spread the link of the online questionnaire to different departments within the faculty. The students were asked to give a response to the questionnaire based on their perspective and experience in using Virtual Class Lampung University as a digital platform during the online learning situation for the last two years. It took the researchers one week to obtain the responses of 272 students. The collected data was later analyzed based on the obtained responses using descriptive statistics and then the responses of each item were analyzed based on the mean value. Several items were designed to have reversed scoring system in which high score indicate negative response.

\section{Results}

The findings of this research were responses of 272 students in the Faculty of Teacher Training and Education to 14 questionnaire items. 13 items were close ended Likert-scale items, while 1 item was open-ended item. The close-ended items were analyzed to identify the statistical value of overall responses from 272 students. Given below is the table showing the descriptive statistics of the students' responses.

Table 2. Statistics of the questionnaire responses

\begin{tabular}{|c|c|c|c|c|}
\hline No. & Statement & Mean & $\begin{array}{c}\text { Std. } \\
\text { Deviation }\end{array}$ & $\mathrm{N}$ \\
\hline 1 & $\begin{array}{l}\text { Virtual Class Unila generally provides complete features. } \\
\text { Virtual Class Unila memiliki fitur yang cukup lengkap. }\end{array}$ & 3.24 & .579 & 272 \\
\hline 2 & $\begin{array}{l}\text { Overall, the varied features in Virtual Class Unila are very helpful in online } \\
\text { learning situation. } \\
\text { Secara umum, ragam fitur dalam Virtual Class Unila sangat membantu proses } \\
\text { pembelajaran daring. }\end{array}$ & 3.31 & .615 & 272 \\
\hline 3 & $\begin{array}{l}\text { Features in Virtual Class Unila still cannot provide practical courses optimally. } \\
\text { Fitur-fitur dalam Virtual Class Unila masih belum optimal dalam menunjang } \\
\text { pembelajaran berbasis praktikum. }\end{array}$ & 3.02 & .833 & 272 \\
\hline 4 & $\begin{array}{l}\text { Virtual Class Unila can provide asynchronous and synchronous discussion with } \\
\text { the features within it. } \\
\text { Virtual Class Unila dapat mengakomodir kegiatan diskusi asinkronus maupun } \\
\text { sinkronus dengan baik dengan ragam fitur di dalamnya. }\end{array}$ & 3.03 & .645 & 272 \\
\hline
\end{tabular}




\begin{tabular}{|c|c|c|c|c|}
\hline 5 & $\begin{array}{l}\text { Interactive quiz in Virtual Class Unila is very helpful in reinforcing materials. } \\
\text { Fitur kuis interaktif sangat membantu dalam evaluasi dan penguatan materi } \\
\text { kuliah. }\end{array}$ & 3.26 & .668 & 272 \\
\hline 6 & $\begin{array}{l}\text { Virtual Class Unila should provide more than one video conference platform. } \\
\text { Virtual Class Unila seharusnya menyediakan lebih dari satu media untuk } \\
\text { melakukan video conference. }\end{array}$ & 3.46 & .664 & 272 \\
\hline 7 & $\begin{array}{l}\text { I feel that H5P (HTML5) is rarely used by lecturers. } \\
\text { Saya merasa penggunaan fitur H5P (HTML5) masih jarang dilakukan oleh } \\
\text { dosen. }\end{array}$ & 3.03 & .673 & 272 \\
\hline 8 & $\begin{array}{l}\text { Lecturers should be able to optimize all features within Virtual Class instead of } \\
\text { using the same features repetitively. } \\
\text { Dosen harus lebih mengoptimalkan ragam fitur di dalam Virtual Class dan } \\
\text { tidak menggunakan fitur yang itu-itu saja. }\end{array}$ & 3.51 & .625 & 272 \\
\hline 9 & $\begin{array}{l}\text { Internet connection problem does not affect Virtual Class that much. } \\
\text { Virtual Class Unila tidak terlalu terpengaruh oleh gangguan jaringan. }\end{array}$ & 1.74 & .807 & 272 \\
\hline 10 & $\begin{array}{l}\text { Some features have never been used by lecturers, while some others are used } \\
\text { too often. } \\
\text { Beberapa fitur dalam Virtual Class Unila tidak pernah digunakan oleh dosen, } \\
\text { sementara beberapa yang lainnya terlalu sering digunakan. }\end{array}$ & 3.03 & .736 & 272 \\
\hline 11 & $\begin{array}{l}\text { The online attendance in Virtual Class is very easy to use and helpful. } \\
\text { Fitur daftar hadir dalam Virtual Class sangat membantu dan mudah } \\
\text { digunakan }\end{array}$ & 3.02 & .746 & 272 \\
\hline 12 & $\begin{array}{l}\text { Features in Virtual Class Unila still can be added. } \\
\text { Fitur-fitur di dalam Virtual Class Unila masih belum cukup banyak. }\end{array}$ & 2.95 & .722 & 272 \\
\hline 13 & $\begin{array}{l}\text { The appearance and interface of Virtual Class Unila are interesting } \\
\text { Tampilan Virtual Class Unila sudah cukup menarik. }\end{array}$ & 3.06 & .734 & 272 \\
\hline
\end{tabular}

From the Table 2, it can be seen that most items are getting positive reactions by getting more than 3 points on average. Most of the students believe that Virtual Class Unila, despite several weaknesses, is very helpful in tackling the difficulties during online learning situation during the pandemic.

However, five items, which are number 3, number 7, number 8, number 9 and number 12, got negative reactions. Item numbers 3, 7, 8 and 12 are reversed statements that make them get negative results should they get high-scored responses from the students. Meanwhile, item number 9 got the mean score of 1.74 that was less than a half of the total mean score.

Item number 3 is a reversed statement that indicates Virtual Class lacking features in providing practical courses. The responses to item number 7 indicate that students expect the lecturers to use a certain feature more frequently. Item number 8 is a reversed statement which implied students wish to have their lecturers using more features given in the Virtual Class. Item number 9 indicates a common perspective among students regarding the unstable server of Virtual Class which was often got interrupted by poor internet connection. Meanwhile, item number 12 is a reversed statement that implies some more features that could be added to Virtual Class. Moreover, the negative responses to item number 12 was proof that responses to item number 8 are valid in which not many lecturers optimize all features in Virtual Class, making the students less familiar to the types of features within the learning management system. However, the overall responses were positive and very important to the development of Virtual Class in the future.

The next part of the data was the optional responses to the open-ended item within the questionnaire. This item was designed to see further perspectives and opinions of the students regarding the Virtual Class. The item aimed to trigger the students to make some additional responses to enrich the close-ended data. Given below are some categories of the open-ended responses from students of the Faculty of Teacher Training and Education. Since this part was optional, only around 150 wrote their responses.

Table 3. Categorized responses to open-ended item based on the analysis

No
Categories based on the open-ended responses
Excerpts of students' responses
Number of students responding within the categories 
Unila needs to provide a better system • Unstable connection sometimes

to avoid disruption during online disturbs us in completing activities. I

learning using Virtual Class. think regular maintenance is needed.

- Sometimes my Virtual Class is suddenly closed due to unexplained issue.

- Almost every 8 in the morning, and 1 in the afternoon, the server is unresponsive.

\begin{tabular}{|c|c|c|c|}
\hline 2 & $\begin{array}{l}\text { More Video Conference Platforms need } \\
\text { to be installed in Virtual Class. }\end{array}$ & $\begin{array}{l}\text { - Having Zoom in Virtual Class will be } \\
\text { very nice. } \\
\text { - I think it would be better to use } \\
\text { Zoom since it has the break out room } \\
\text { feature. }\end{array}$ & 8 \\
\hline 3 & $\begin{array}{l}\text { More features need to be installed in } \\
\text { Virtual Class, especially for practical } \\
\text { courses. }\end{array}$ & $\begin{array}{l}\text { - Virtual Class still cannot provide } \\
\text { practical activities properly especially } \\
\text { for science-related courses. }\end{array}$ & 10 \\
\hline 4 & Virtual Class is very user-friendly. & $\begin{array}{l}\text { - It is very easy to operate and navigate } \\
\text { the materials in Virtual Class. } \\
\text { - Having the lecturer as facilitator and } \\
\text { Virtual Class as the media is very } \\
\text { helpful in online learning }\end{array}$ & 70 \\
\hline 5 & $\begin{array}{l}\text { Virtual Class } \text { needs } \underset{\text { a }}{\text { more }} \\
\text { sophisticated and efficient interface. }\end{array}$ & $\begin{array}{l}\text { - Some updates to improve its } \\
\text { appearance and interface would be } \\
\text { nice. } \\
\text { - V-Class should be more thematic. }\end{array}$ & 12 \\
\hline 6 & $\begin{array}{l}\text { It is very useful during the pandemic } \\
\text { situation }\end{array}$ & $\begin{array}{l}\text { - Using Virtual Class is better than } \\
\text { having online class via instant } \\
\text { messenger such as WhatsApp. } \\
\text { - Virtual Class can help me to learn } \\
\text { better since it does not have many } \\
\text { distractions such as advertisements, } \\
\text { link to unnecessary contents, or even } \\
\text { chat notifications. }\end{array}$ & 150 \\
\hline
\end{tabular}

Based on Table 3, it can be seen that most of the correspondences believe that internet connection and the unstable server is the main problem despite the fact that Virtual Class is very user-friendly and easy to be operated. Meanwhile, some students believe that more features and updates on the interface are necessary to develop Virtual Class. The additional features are expected to provide a better practical experience for some courses. Only a few of them mentioned the urgency of adding more video conference platforms beside the existing Google Meet within the system while everyone who responded to the open-ended item believes that Virtual Class is a tremendous help in such difficulties of online learning conditions during the pandemic.

\section{Discussion}

This study has shown several responses regarding the use of Virtual Class in the scope of Faculty of Teacher Training and Education, Lampung University. As it has been described in the findings, most of the students believed that Virtual Class Unila is essential and helpful to be used in online learning situations. However, it is believed that several improvements are necessary to be added to the system and most students have a similar issue with the unstable server.

The findings of this study are in line with some previous studies about the implementation of online learning management systems, teaching media and the application of online digital media in EFL classrooms. The responses of students regarding different helpful features in Virtual Class prove that (Turnbull et al., 2020) with their findings on how a solid learning management system (LMS) with varied features, help the learning process is valid. Moreover, in line with (Ippakayala \& El-Ocla, 2017) on LMS to support distant learning, the finding of this study has proven the essential role of LMS during a pandemic situation which requires most schools to conduct distant learning through the Internet.

Meanwhile, several issues pointed out by the students such as lack of optimization of features by lecturers and also unstable server indicate valid findings by (Gunduz \& Ozcan, 2017) and (Ahmada \& YIN, 2019) which stated 
the importance of decent preparations and also heavy modification in using such online platform to support learning process.

Moreover, in line with (Muhammad et al., 2017), the findings of this study prove that students demand interactive elements such as thematic layout and intriguing features in order to help them learn better.

\section{Conclusion}

Overall, this current study has been able to prove the essential role of LMS in distant learning situations. This study also supports some previous findings on particular fields of EFL especially in developing a proper learning management system. Varied responses from students have answered that LMS is essential, but at the same time needs to be developed by tackling some technical issues and optimizing existing features.

Furthermore, this study is expected to open more chance for researchers in the field of teaching media to explore more possibilities in the development of learning management system. More than that, the findings of this study are hopefully utilized to develop Virtual Class as it has become essential part of the distant learning platform for the institution.

Finally, the current study is limited to the perceptions of undergraduate students within the Faculty of Teacher Training and Education, Universitas Lampung. Further study regarding the implementation of learning management system and how it influences the learning process and learning achievement should be done to obtain deeper understanding on the particular field of modern teaching media.

\section{Acknowledgements}

We would like to express gratitude to all parties taking part in this study.

\section{Funding}

This research received institutional grant from University of Lampung with the following grant number: 3492/UN26.13/PN.01.00.02/2021.

\section{References}

Adzharuddin, N. A., \& Ling, L. H. (2013). Learning Management System (LMS) among University Students: Does It Work? International Journal of E-Education, e-Business, e-Management and e-Learning (IJEEEE), 3(3), 248-252. doi: 10.7763/IJEEEE.2013.V3.233

Ahmada, N. A., \& YIN, K. Y. (2019). Using interactive media to support reading skills among underachieving children. International Journal of Innovation, Creativity and Change, 8(7), 81-88.

Atmojo, A. E. P., \& Nugroho, A. (2020). EFL classes must go online! Teaching activities and challenges during COVID-19 pandemic in Indonesia. Register Journal, 13(1), 49 - 76.

Aydin, S. (2007). Attitudes of EFL learners towards the Internet. Turkish Online Journal of Educational Technology, 6(3), 18-26.

Gunduz, N., \& Ozcan, D. (2017). Implementation of the Moodle system into EFL classes. Profile Issues in Teachers' Professional Development, 19(1), 51-64. doi:10.15446/profile.v19n_sup1.68571

Ippakayala, V. K., \& El-Ocla, H. (2017). OLMS: Online Learning Management System for e-learning. World Journal on Educational Technology, 6(3), 130. https://doi.org/10.18844/wjet.v6i3.1973.

Kobayashi, M. (2017). Students' media preferences in online learning. Turkish Online Journal of Distance Education, 18(3), 4-4 10. doi:10.17718/tojde.328925

Koohang, A., \& Durante, A. (2003). Learners' perceptions toward the web-based distance learning activities/assignments portion of an undergraduate hybrid instructional model. Journal of Informational Technology Education, 2, $105-113$.

Muhammad, S., Muslem, A., \& Sari, D. F. (2017). The students' perceptions toward teacher's way in teaching reading comprehension. Research in English and Education (READ), 2(1), 83-92.

Qiong, O. U. (2017). A brief introduction to perception. Studies in Literature and Language, 15(4), 18-28.

RAO, P. S. (2019). The impact of social media on learning English: A critical study in English language teaching (ELT) context. Research Journal of English (RJOE), 4(2), 266-274.

Shafwati, D., Sholihah, L., Prakoso, G. H., \& Riyantika, F. (2021). The use of YouTube video toward students' listening ability. ICOPE 2020: Proceedings of the 2nd International Conference on Progressive Education, ICOPE $2020,105-112$.

Smart, K., \& Cappel, J. (2006). Students' perceptions of online learning: A comparative study. Journal of Information Technology Education, 5, 201-219.

Turnbull, D., Chugh, R., \& Luck, J. (2020). Learning Management Systems: An overview. International Journal of Research \& Method in Education, 44(4), 1-15. https://doi.org/10.1080/1743727X.2020.1737002

Zarei, A., Maryam, Z., \& Amani, A. (2018). The Effect of Online Learning Tools on L2 Reading Comprehension and Vocabulary Learning. Journal of Teaching Language Skills (JTLS), 37(3), 211-238. https://doi.org/10.22099/jtls.2019.32248.2637. 